\title{
Lithium carbonate toxicity in an elderly patient: a case report
}

\author{
Ankit Bhardwaj ${ }^{1 *}$, Vandana Roy ${ }^{2}$, Manik S. Ghadlinge's ${ }^{1}$, Anubhav Dua ${ }^{3}$
}

\author{
${ }^{1}$ Department of Pharmacology, ABVIMS and RML Hospital, Delhi, India \\ ${ }^{2}$ Department of Pharmacology, MAMC and LNJP, Hospital, Delhi, India \\ ${ }^{3}$ Department of Psychiatry, SIMS, Hapur, Uttar Pradesh, India
}

Received: 17 April 2021

Accepted: 10 May 2021

\section{*Correspondence:}

Dr. Ankit Bhardwaj,

Email: drankitbhardwaj25@gmail.com

Copyright: $@$ the author(s), publisher and licensee Medip Academy. This is an open-access article distributed under the terms of the Creative Commons Attribution Non-Commercial License, which permits unrestricted non-commercial use, distribution, and reproduction in any medium, provided the original work is properly cited.

\begin{abstract}
A case report of a 73-year-old man admitted in the intensive care unit with acute renal failure and lithium toxicity is reported. Lithium is a gold standard drug for bipolar disorder. It has a narrow therapeutic index and requires blood level monitoring frequently. Hemodialysis is the last resort in management of lithium toxicity but in between high rebound levels during the dialysis result in persistent CNS toxicity.
\end{abstract}

Keywords: Lithium toxicity, Pharmacokinetics, Therapeutic drug monitoring, Hemodialysis

\section{INTRODUCTION}

Lithium is an effective medication for the treatment of bipolar disorder. National institute for health and care excellence (NICE) guidelines recommend it as the firstline pharmacological treatment for long-term management of bipolar disorder. ${ }^{1}$ However, lithium's narrow therapeutic range $(0.6-1.2 \mathrm{mmol} / \mathrm{l})$ requires regular follow up of patient after every 2-3 months to prevent toxicity. ${ }^{1}$ The clinical manifestations of lithium toxicity are manifold, involving multiple systems and can be acute, acute-on-chronic, or chronic. ${ }^{2}$ Lithium poisonings can be associated with infections or medicine, the most frequent being with diuretics or angiotensinconverting enzyme inhibitors. ${ }^{3}$

We present a case of bipolar disorder that was stable on lithium treatment for the last 7 years and presented with acute renal failure.

\section{CASE REPORT}

A 73 year old man was admitted to the intensive care unit (ICU) for altered behavior, irrelevant talking and increased tremors in both hands, and ataxia. He was receiving $450 \mathrm{mg}$ twice-daily lithium carbonate for a bipolar disorder without any recent change in his drug regimen for more than 7 years. His last lithium level was $0.8 \mathrm{mmol} / \mathrm{l}, 8$ months before admission. His physical examination showed altered behavior with bilateral nystagmus, sensory and motor defects. He was afebrile and there was no hemodynamic or respiratory failure. Urine output was less than $150 \mathrm{ml}$ over 6 hours. His laboratory parameters were as follows: white blood cell $10,800 / \mathrm{mm}^{3}$; hemoglobin $8.0 \mathrm{~g} / \mathrm{dl}$; platelet count 202,000/. $\mathrm{mm}^{3}$; creatinine $5.6 \mathrm{mg} / \mathrm{l}$; urea $192 \mathrm{mmol} / \mathrm{l} ; \mathrm{K}^{+}$ $5.3 \mathrm{meq} / \mathrm{l} ; \mathrm{Na}^{+} 137 \mathrm{meq} / \mathrm{l} ; \mathrm{Cl}^{-} 104 \mathrm{meq} / \mathrm{l}$; blood gas sample pH-7, $\mathrm{PO}_{2} 95 \mathrm{mmHg} ; \mathrm{PCO}_{2} 31 \mathrm{mmHg} ; \mathrm{HCO}_{3} 24$ meq/l. SGPT 13 IU/l; SGOT $10 \mathrm{IU} / \mathrm{l}$; bilirubin $0.1 \mathrm{mg} / \mathrm{l}$; screening test for benzodiazepine, barbituric and tricyclic antidepressant were negative. High resolution computer tomography of brain showed mild age-related atrophy, but did not show any bleeding or ischemic stroke.

The electrocardiogram showed slight PR prolongation, T wave inversion and old myocardial ischemia. The lithium level obtained was $4.2 \mathrm{mmol} / \mathrm{l}$. The patient's family members denied any recent changes in lithium brand, 
dosage, any intentional or accidental overdose as he was taking the medicine under supervision of his son.

Hemodialysis was planned immediately and a total of 4 hemodialysis on alternate days was done. Lithium concentration was determined on admission, at the beginning, and at the end of each hemodialysis session. Lithium level decreased significantly but increase in Lithium happened after second hemodialysis (Figure 1). Cessation of hemodialysis session was done after serum lithium levels reached $1.2 \mathrm{mmol} / \mathrm{l} 6$ hours after the last hemodialysis.

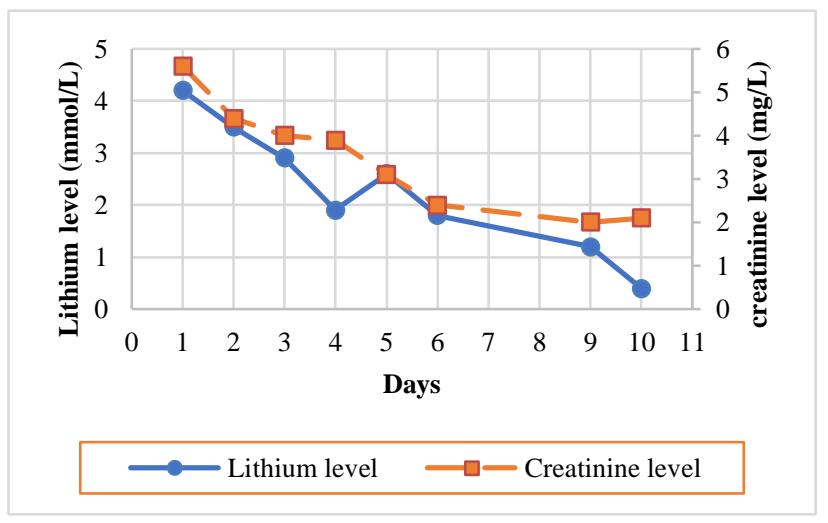

\section{Figure 1: Serum lithium and creatinine level followed} every hemodialysis.

Kidney function went back to near normal range with a urine output of $1000 \mathrm{ml} / 24$ hours, serum creatinine 2.1 $\mathrm{mg} / \mathrm{l}$ and serum lithium levels 0.4 on day 10 . Patient was kept under observation for three more days in indoor patient ward and discharged on a satisfactory note. We failed to find any infectious or iatrogenic trigger which could have led to this extremely high lithium concentration and acute renal failure. We cannot formally exclude an accidental lithium overdose resulting in acute kidney injury with oliguria.

\section{Follow up}

Lithium was stopped and patient was switched to valproic acid. Ataxia and dysarthria still persist.

\section{DISCUSSION}

Lithium recommendations in geriatric psychiatry patients are based on extrapolations from pharmacokinetics studies, anecdotal reports and clinical experience. Acute lithium toxicity is characterized by nausea, vomiting, diarrhea, dysrhythmia, cardiac conduction changes and neurological manifestations such as coarse tremor, muscle weakness, cerebellar signs and delirium. Severe lithium toxicity can cause seizures; coma and permanent neurological effects such as dementia. ${ }^{4}$

Neurological side effects are most common in chronic toxicity. Age over 50 year, renal disease (nephrogenic diabetes insipidus or renal failure), thyroid failure and treatment with angiotensin-converting enzyme (ACE) inhibitors, thiazide diuretics and prolonged treatment with NSAIDs, sodium or volume depletion are key factors for lithium accumulation and neurotoxicity. ${ }^{5}$ In a retrospective analysis by Oakley et al they found that severe neurological symptoms occur more likely at higher serum lithium levels $(>2.3 \mathrm{mmol} / \mathrm{l})$. Patient presenting with chronic poisoning are at greater risk of severe neurotoxicity than those presenting after an isolated acute lithium overdose. ${ }^{6}$ This patient is in $70 \mathrm{~s}$ and could have had age-related renal dysfunction, not diagnosed before. The also did not come for nearly 8 months for monitoring of serum lithium levels. This could be considered high risk for lithium toxicity.

Brain imaging (high resolution computed tomography) showed mild age-related atrophy. Determining the underlying brain region dysfunction caused by lithium toxicity was difficult.

Despite persistence hemodialysis 'lithium rebound' may also have been a contributory factor for clinical deterioration in between the hemodialysis. This can be explained by redistribution of lithium from deeper compartments/red blood cells to the plasma and may be associated with recurrence of symptoms or clinical deterioration, because the absorbed drug will ultimately distribute into the CNS and other tissues. Barth et al suggest that damage may be widespread and persist with neurological toxicity due to accumulation and rebound at CNS level. ${ }^{7}$

Recent research recommends a low mean serum lithium concentration (approximately $0.5 \mathrm{mmol} / \mathrm{l}$ ), which may be achieved by using a mean dose of $400 \mathrm{mg}$ /day in a singledose extend release regimen. ${ }^{7}$ The dosage recommended amongst patients aged between 65 and 75 years ranges from 300 to $600 \mathrm{mg} /$ day and rarely exceeds $900 \mathrm{mg} / \mathrm{day}$. For patients aged more than 80 years or frail elderly, the dosage should range from 150 to $300 \mathrm{mg}$ /day and should rarely exceed $450 \mathrm{mg} /$ day. $^{7}$ Second line medication considered appropriate for monotherapy include lamotrigine, olanzapine, quetiapine and valproate.

In present case report, the lithium dose was higher than recommended for older adults. The patient also did not come for monitoring of serum lithium for over 8 months. Lower doses of lithium should be used considering age related pharmacokinetics and pharmacodynamics changes. Clinical manifestations of lithium toxicity are heterogeneous in elderly, and may not be related to dose or serum concentration. Polypharmacy and medical morbidities are quite common in the elderly, playing important precipitating factors of lithium toxicity, thus requiring more clinical vigilance. Though hemodialysis is last resort for management of lithium toxicity, but rebound increase in lithium level can cause irreversible CNS damage. 


\section{CONCLUSION}

In elderly patients requiring lithium extra caution is required for dosing. Patient and their families must be educated about the importance of dose and regular monitoring of serum lithium levels.

\section{Recommendations}

Severe potential risk factors (hypertension, diabetes, degree of renal impairment, and co-medications) should be considered while prescribing lithium in elderly. In older patient's serum lithium level should routinely be monitored at least every 2-3 months along with renal functions every 3-6 months, metabolic and endocrine testing every 6 months. Cognitive testing should be done using the MMSE or MoCA to assess any underlying chronic lithium neurotoxicity.

Funding: No funding sources Conflict of interest: None declared Ethical approval: Not required

\section{REFERENCES}

1. National institute for health and care excellence (NICE) (2014) bipolar disorder: assessment and management, NICE Guideline (CG185) Available at: https://www.nice.org.uk/guidance/cg185. Accessed on 20 February 2021.

2. Baird-Gunning J, Lea-Henry T, Hoegberg LCG. Lithium poisoning. J Intensive Care Med. 2017;32: 249-63.
3. Ott M, Stegmayr B, Salander-Renberg E, Werneke U. Lithium intoxication: incidence, clinical course and renal function a population-based retrospective cohort study. J Psychopharmacol. 2016;30(10):100819.

4. Offerman SR, Alsop JA, Lee J, Holmes JF. Hospitalized lithium overdose cases reported to the California poison control system. Clin Toxicol. 2010;48(5):443-8.

5. Katsung BG, Masters SB, Trevor AJ, Meltzer H: Antipsychotic agents and lithium. In: Basic and clinical pharmacology. 12th ed. USA: McGraw-Hill Medical; 2012:501-20

6. Oakley PW, Whyte IM, Carter GL. Lithium toxicity: an iatrogenic problem in susceptible individuals. Aust J Psychiatry. 2001;35:833-40.

7. Barth J, Munder T, Gerger H, Nüesch E, Trelle S, Znoj $\mathrm{H}$, et al. Comparative efficacy of seven psychotherapeutic interventions for patients with depression: a network meta-analysis. PLoS Med. 2013;10(5):e1001454.

8. Peces R, Fernández EJ, Regidor D, Peces C, Sánchez R, Montero A, Selgas R. Treatment of acute lithium intoxication with high-flux haemodialysis membranes. Nefrologia. 2006;26(3):372-8.

Cite this article as: Bhardwaj A, Roy V, Ghadlinge's MS, Dua A. Lithium carbonate toxicity in an elderly patient: a case report. Int J Basic Clin Pharmacol 2021;10:766-8. 